\title{
Can Parliaments be Strengthened? A Case Study of Pre-Legislative Scrutiny
}

\author{
Catherine Lynch \\ Oireachtas Library and Research Service \\ catherine.lynch@oireachtas.ie \\ Shane Martin \\ University of Essex \\ shane.martin@essex.ac.uk
}

Forthcoming, Irish Political Studies

\begin{abstract}
How successful are attempts to strengthen the capacity of national legislatures to better perform their law-making function? In response to executive dominance, some legislatures have attempted organizational reform to strengthen their capacity. One such institutional innovation is pre-legislative scrutiny (PLS) - a process whereby a parliamentary committee scrutinizes draft bills and reports back with observations and/or recommendations to the ministry sponsoring the legislation. PLS is designed to enhance the capacity of parliament to influence government-sponsored legislation. We measure the impact of PLS on legislative outcomes by conducting a content analysis of PLS reports and subsequent Government bills introduced to the Irish Parliament between 2011 and 2016. This analysis is supplemented with an in-depth case study of legislative change around gender recognition. The mixed method analysis suggesting that PLS can have a substantive impact on proposed government legislation. PLS serves to strengthen the role of parliament in law-making, with positive, and arguably generalizable, consequences for stakeholder engagement, parliamentarians and the quality of legislation.
\end{abstract}

Keywords: Legislatures; Parliaments; Parliamentary Capacity Building; Pre-Legislative Scrutiny; Oireachtas; Parliamentary Reform; Dáil Reform; Parliamentary Committees 
Legislatures may be the cornerstone of representative democracy, but they often live in the shadow of the executive. ${ }^{1}$ The imbalance in the relative power of the executive and legislature is a widely-discussed theme in the comparative study of parliamentary government (see for example, Huber, 1996 and Martin et al., 2014), and the study of Irish politics is no different (see for example, MacCarthaigh, 2005; MacCarthaigh, 2019; O'Malley and MacCarthaigh, 2011; and O'Malley and Martin, 2018). In response to executive dominance, some legislatures have attempted organizational reform to strengthen their capacity. Such parliamentary capacity building programs - a broad term to describe institutional reform and additional resource allocation aimed at allowing parliament to more effectively perform its constitutional function - are now common in both well-established democracies and countries in transition to democracy.

But do parliamentary capacity building programs actually work? To help answer this question, we explore the impact of one popular capacity-enhancing reform: the development and adoption of Pre Legislative Scrutiny (PLS) by parliament. PLS is a process whereby the executive sends early drafts of proposed legislation to legislative bodies which then analyses the policy proposals and reports its observations and/or recommendations to the ministry sponsoring the draft legislation (in a report which is generally laid before the Dáil). As Smookler (2006: 522) notes, "PLS typically involves scrutiny by a parliamentary committee before the final drafting of a Bill has been decided and before the formal legislative process begins." 2

Specifically, our aim in this paper is to help evaluate whether or not PLS permits engagement with, and causes changes to, a Government Bill (and thus public policy). To do this, a mixed method approach is employed. The quantitative research focuses on Government bills introduced to the Irish Parliament between March 2011 and February 2016. This involves a content analysis of the bill drafts, transcript of Committee hearings, submissions received, committee PLS Report and recommendations (if any), and the published Bill. A case study of the Gender Recognition Bill 2014 supplements this quantitative assessment, providing a better

\footnotetext{
${ }^{1}$ We use the terms assemblies, parliaments, and legislatures interchangeably throughout this paper.

2 PLS can be contrasted with other forms of legislative scrutiny, including examination of a Bill as it progresses through the law-making process. Post-legislative scrutiny involves the scrutiny of enacted legislation to determine the degree to which the objectives of the legislation were and are being achieved.
} 
understanding of the PLS process in action from the perspective of parliament, the executive, and policy stakeholders. To anticipate, we find that PLS has helped the Irish parliament become a far more impactful actor in shaping the content of Government legislation.

Reforms to parliaments are important because they often represent an attempt to overcome executive dominance by enhancing parliament's capacity to carry out its constitutional duties - legislative and representative (Koß, 2018; Sieberer, 2016). It is important therefore to understand if reforms, such as the introduction of PLS, help build parliamentary capacity or if such efforts are ultimately for naught. Analysis of the Irish case provides valuable insights into the effectiveness of parliamentary reform that have, we will suggest, generalizable implications.

The remainder of the paper is organized as follows: Next, we discuss PLS in a comparative context, including research focused on measuring the effectiveness of the process. We then introduce the Irish case and review the operation of PLS. Subsequently, we introduce our methodology and present findings. The evidence suggests that PLS can have a very real and substantive impact on proposed government legislation. We conclude with a discussion of the broader consequences and suggestion for further research.

\section{PLS: An overview and existing evidence}

PLS is a relatively recent innovation. It is not widely practiced in the parliaments of Europe and is practiced to a limited extent in parliaments of the Westminster tradition. ${ }^{3}$ The United Kingdom was one of the first national legislatures to experiment with PLS and it is here that the process has been most developed. The Conservative administrations of the late 1980s and early 1990s trialled the parliamentary scrutiny of draft Bills, but PLS has only become an established feature of parliamentary life since 1997. PLS in the UK Parliament is at the discretion of the Government; there is no obligation on government to refer a bill in draft

\footnotetext{
${ }^{3}$ On the other hand, in the vast majority of parliaments bills are firstly referred to the relevant parliamentary committee which deliberates on the bill, frequently holding hearings and inviting written submissions. It then sends a report to parliament. See Oireacthas Library and Research Service (2014 p.6) for a summary of PLS's application in Europe and in select parliaments from the Westminster tradition (p.7-8).
} 
format to parliament for PLS. This is also the case in the Scottish and New Zealand parliaments and in the Australian Federal Parliament.

Most analysis of PLS and its impact in the UK indicates that the experimentation has been positive for the role of Parliament in law-making and for the quality of legislation. Exploring the 1997-99 period, Power (2003: 3) concluded that "the use of draft Bills for consultation is widely regarded as an effective way of improving the quality of legislation." A 2006 Modernisation Committee report on the UK's Legislative Process concluded that: "[T]here is little doubt that pre-legislative scrutiny produces better laws." Exploring the impact of PLS through a case study of two Bills, Smookler (2006: 534) concluded that PLS has a "proven record of influencing a Bill's content before it is entrenched, and providing a locus of guidance for parliamentarians, demonstrating its value as a significant contributor towards the development of better legislation." Kalitowski (2008) and Korris (2011) have pointed to the benefit of PLS in the British case as a counterbalance to perceived executive dominance in the law-making process. Norton (2013: 84) suggests that "[b]y being able to have some input at the formulation stage, parliamentary influence is maximised." Goodwin and Bates (2016) studied the impact of PLS on the Human Fertilisation and Embryology Bill, concluding that "Parliament was at its most powerful in the pre-legislative, rather than the legislative phase, and its power was principally exercised in setting the agenda rather than in formal decision making" (Goodwin and Bates 2016: 233).

Yet, the experience of PLS at Westminster has not been without criticism. As Russell and Gover (2017: 229) note, most Bills are not subject to PLS in the UK Parliament. The Government decides which Bills are subject to PLS (Norton 2013: 84). PLS can also be a resource drain on MPs and one former MP reflected (Widdecombe 2005: 8) that this could limit the effectiveness of select committees: "the committee can become so bogged down in examination of proposed Bills that it is restricted in the development of its own programme of work and finds its agenda driven by Government priorities rather than its own."

As beneficial as the above research and perspectives are, a number of shortcomings are evident: first, the research, to the best of our knowledge is exclusively focused on the UK case. The UK Parliament has unusual features - such as how the committee system is organized - 
which may mean that the results of the UK research are not generalizable to other legislatures. ${ }^{4}$ Further, PLS is at the discretion of the UK government rather than parliament, which arguably weakens the extent to which PLS strengthens parliament. Our aim then in the rest of the paper is to help fill the lacuna around the impact of PLS by exploring the impact of the phenomenon in the Irish case.

\section{Parliamentary Politics in Ireland and PLS}

The need for political reform dominated the 2011 Irish general election campaign in an unprecedented way. High on the reform agenda was the perceived failure of Ireland's political institutions, including parliament, to play a role in averting the economic and financial crisis. (Oireachtas Library and Research Service, 2011, Gallagher and Marsh 2011). The weakness of the Irish Parliament in terms of executive oversight and political and institutional capacity to influence the Government's legislative agenda had been well documented in the academic literature. MacCarthaigh $(2005,2011)$ bemoaning the inability of the Dáil to hold Government Departments and agencies accountable. Gallagher (2010) finds that the Government dominates Parliament. Murphy (2006) suggests that reforms to strengthen Oireachtas Committees had failed to redress the imbalance of power between the executive and legislature.

Committees - the key mechanism by which a legislature develops the ability to counterbalance the many advantages of the executive in terms of policy development (Strøm, 1998) have traditionally been described with terms such as 'weak', 'ineffective' and 'underdeveloped' in the Irish Parliament (André et al. 2016). The perceived historical weakness of committees in the Oireachtas at least partly explains the overall weakness of the Irish parliament, particularly in relation to the executive. In recent decades, significant developments in the operation and role of committees in the Oireachtas are evident. These reforms, beginning in the 1980s, have

\footnotetext{
${ }^{4}$ In the UK Parliament, committee work is divided between permanent committees (which, broadly speaking, shadow government Departments) and bills committees (which may be formed to scrutinise a specific piece of proposed legislation at the committee stage). As such, the committee scrutinising proposed legislation is not the committee that otherwise oversees the activities of government departments. Moreover, the UK Parliament tends to an adversarial government-opposition culture which may make it more difficult for committees to act in a non-partisan fashion. (Martin and Whitaker 2019).
} 
seen an effective redesign of the Committee system on a number of occasions (Arkins 1988; Lynch 2017; Martin 2010).

Against this backdrop, the Programme for Government 2011-2016 proposed a package of parliamentary reforms to make for a more effective and efficient Oireachtas. Included in the Programme was the commitment that the Government "[w]ill enhance the democratic process by involving public representatives at an earlier stage of the legislative process, particularly before Bills are published" (Programme for Government 2011-2016: 21).

Pre-legislative scrutiny (PLS) was introduced to the Houses of the Oireachtas in 2011 - when cabinet procedure was amended to allow Ministers to publish legislation in draft format, following its approval by Cabinet. In November 2013 Dáil Standing Orders were amended to provide for a formal process of pre-legislative scrutiny. As a result, Ministers are now required to forward draft legislation - the General Scheme or Heads of a Bill - to the relevant Oireachtas Joint Committee for possible scrutiny except in exceptional circumstances. ${ }^{5}$ Updated Oireachtas procedures view PLS as standard practice, unless otherwise agreed (save in exceptional circumstances and by permission of the Business Committee). ${ }^{6}$ A PLS Protocol, agreed between the Government and the Houses of the Oireachtas Service in October 2014, required Departments to appoint a PLS Coordinator to notify Oireachtas Committees about the General Schemes expected for publication and sets out that Joint Committees should have eight weeks to produce a response from the time the General Scheme is referred (before the government begins the formal drafting of the bill).The government of the $32^{\text {nd }}$ Dáil includes notification of General Schemes in its six-monthly legislative programme.

Draft legislation or a legislative proposal is the 'General Scheme' or 'Heads' of a Bill, which presents a sequential overview of the planned content of the Bill. In general, PLS by Oireachtas Committees in the $31^{\text {st }}$ Dáil (2011-2016) operated in the following way (although different Oireachtas Committees can, and have, operated differently):

\footnotetext{
${ }^{5}$ Standing Order Dáil Eireann 146A (as amended)

${ }^{6}$ The Business Committee is a cross-party committee chaired by the Ceann Comhairle (presiding officer) of the Dáil (lower House) which agrees the business of the Dáil. It was established as a reform in the $32^{\text {nd }}$ Dáil.
} 
- General Scheme is published and referred to the relevant Oireachtas Committee by the Minister.

- The Committee decides whether to carry out PLS. If the Committee decides to carry out PLS:

- The Committee generally invites submissions, either through an open or a targeted call;

- The Committee generally requests research support from the Oireachtas Library \& Research service;

- The Committee may hold public hearings with Department representatives, stakeholders, and/or experts;

- The Committee meets to discuss issues arising during its scrutiny of the draft legislation; and

- The Committee publishes its assessment of the General Scheme and sends it to the Minister (and generally lays it before the Houses) ${ }^{7}$

Joint Committees of the Houses of the Oireachtas completed 52 cases of pre-legislative scrutiny. In 45 cases, an Oireachtas Committee produced a report, in six cases the Committee responded by way of letter to the Minister, and in one case (the General Scheme Securities Market Programme Bill) the Committee forwarded a copy of transcripts of its hearings to the Minister (Oireachtas Library \& Research Service 2016). This represents a (completed) PLS rate of 20\%; in other words, approximately one in every five Government Bills (of which there were 266) introduced in the $31^{\text {st }}$ Dáil resulted in a completed PLS. When interpreting this rate it should be borne in mind that PLS was only formally introduced in Standing Orders as a requirement in November 2013. 121 Government Bills were published after this date (from November 2013 to the end of the $31^{\text {st }}$ Dáil).

\section{A framework to measure the impact of PLS on legislative outcomes}

We undertake a quantitative analysis of the 52 cases of PLS during the $31^{\text {st }}$ Dáil (March 2011February 2016), supplemented with a case study focused on one bill. The impact of PLS on legislative outcomes is assessed by focusing on (a) the degree to which a Joint Committee makes recommendations, and (b) whether or not these recommendations are actioned by the Minister in the Bill as published. Studying a published Bill provides the most direct route to understand how a Minister has responded to the PLS process.

\footnotetext{
${ }^{7}$ Source: Authors Interviews; Figure 1, Oireachtas Library and Research Service (2014; 2016).
} 
We determine the number and nature of PLS recommendations per Committee Report/Letter. This allows us to contrast the published Bill with both the General Scheme and the PLS recommendations. In particular, content analysis of the published Bill allows us to identify the number of Committee recommendations actually accepted by the Minister at the legislative drafting stage.

The concept of "recommendations" is a key variable, and it is defined as "a suggestion or proposal as to the best course of action, especially one put forward by an authoritative body." 8 We examine every PLS Report (or Letter) to identify recommendations - creating a record of the topic of the recommendation in each case. Most completed PLS cases include a set of recommendations. On the other hand, some PLS reports or communications present no recommendations. Rather, these reports make observations and/or summarise the evidence presented in submissions and/or hearings. An observation or conclusion, including an explicit endorsement by the Committee or suggestion for action, is treated as analogous to a recommendation and is coded as such. On the other hand, if the PLS report simply summarises a submission without expressing an opinion on it, we code this as not being a recommendation. ${ }^{9}$ Summarising the content of a submission or public hearing may have an impact, but it does not send clear signals to a Minister regarding the Committee's preferences.

On identifying impact, when an Oireachtas Committee issues recommendations as part of the PLS process, the Minister faces a number of choices. The Minister can ignore all of the recommendations, accept some recommendations, or he/she can accept all of the Committee's recommendations. Accepting recommendations may require that the General Scheme be revised, resulting, in some instances, in it returning to Cabinet for new approval. A Bill is subsequently published and enters the legislative process, or it remains unpublished. To further explore the causal effect of PLS, cases are compared with amendments to matched Government Bills that went through the Oireachtas but were not subject to PLS.

\footnotetext{
${ }^{8}$ Oxford English Dictionary

${ }^{9}$ This is a practical, methodological decision. A further study would be necessary to examine the extent to which views articulated during the hearings/submissions and highlighted, but not advocated necessarily, by the committee affect the subsequent Bill.
} 


\section{Quantitative Analysis}

The quantitative data presented refers to 50 of the 52 cases undertaken in the $31^{\text {st }}$ Dáil, unless otherwise stated. ${ }^{10}$ Each of the eight PLS-active Committees conducted an average of 6.25 prelegislative scrutinies. As Figure 1 illustrates, there is significant variation between the committees.

<Figure 1 about here>

Across all 52 cases of completed PLS, we identified 467 recommendations (in line with our definition of recommendation set out above). Here, we observe significant variation in the rate of recommendations across committees and the number of recommendations per PLS case. In our study of 52 cases of PLS, eleven of these saw no published Bills before the end of the $31^{\text {st }}$ Dáil. ${ }^{11}$ Interestingly, General Schemes that did not result in a published Bill had a slightly greater number of PLS recommendations than those resulting in a published Bill. PLS reports where a Bill was subsequently published have 8.97 recommendations on average, whereas cases without published Bills contained an average of 10.63 recommendations. In 31 cases, a Joint Committee issued at least one recommendation and a Bill was subsequently presented during the $31^{\text {st }}$ Dáil. Figure 2 summarises the data on recommendation rates.

<Figure 2 about here>

Findings

Our hand-coded content analysis of these 31 reports and the content of the published Bill indicates that 146 of 350 recommendations arising from PLS during this period were accepted by Ministers. This is a recommendation acceptance rate of 41.71 percent. In other words, this analysis finds that just over 40 percent of PLS recommendations were accepted and acted upon

\footnotetext{
${ }^{10}$ We were unable to reach conclusions regarding two PLS cases: The Retention of Records Bill and the Health Information and Patient Safety Bill. The relevant committee did engage in PLS, but no report was produced. We were further unable to locate any communication arising from the PLS process between the committee and the relevant Minister. As such, it is not possible to evaluate the recommendations - if any - or the impact of any recommendations. In both cases, no Bill was published during the lifetime of the $31^{\text {st }}$ Dáil, meaning we cannot measure the difference between the General Scheme and drafted Bill.

${ }^{11}$ By committee, the breakdown for PLS cases for which a Bill was not subsequently published are as follows: Justice, Defence and Equality (7), Environment, Culture and the Gaeltacht (3), and Health and Children (1).
} 
by the Government, with the published Bill reflecting these changes. Thus, on average, just under four recommendations were accepted per PLS case (there is an average accepted recommendation rate per PLS case of 3.74).

In exploring the recommendation acceptance rates by Joint Committees, some interesting trends are evident, as Figure 3 illustrates and notwithstanding the small number of cases of PLS for some Committees. ${ }^{12}$ During the $31^{\text {st }}$ Dáil, the Committee on Jobs, Enterprise and Innovation conducted PLS on two separate General Schemes, issuing (by our analysis) six recommendations on the National Minimum Wage (Low Pay Commission) Bill 2015 and seven recommendations related to the Industrial Relations (Amendment) Bill 2015. By our analysis, the Minister did not accept or action any of these recommendations in the published Bills. All other Departments accepted some of the recommendations arising from PLS, albeit at varying rates. Both Transport and Communications and Health and Children accepted, on average, just over half of the recommendations made arising from PLS.

<Figure 3 about here>

On average, 4.72 months lapsed between referral of a General Scheme and completion of PLS by a Committee, though we observe significant differences between cases. We tested to see if the time between referral of a General Scheme and completion of PLS by a Committee (i.e. the time it takes to issue its report) appeared to have a bearing on the outcome. No statistically significant relationship was found between time used by the Committee to undertake PLS and outcome (the number of recommendations accepted by Government). We did find a weaklynegative correlation between the time which elapsed between referral and completion of PLS and number of accepted recommendations (-0.02). This suggests that as the time between referral and completion of PLS increases the number of recommendations accepted slightly decreases. ${ }^{13}$ This may be because where too much time elapses the Committee loses the opportunity to influence the Bill. However, this relationship is not strong.

\footnotetext{
${ }^{12}$ Agriculture, Food and the Marine undertook one completed PLS, and with three of the four recommendations accepted, this gives a headline acceptance rate of 75 percent.

${ }^{13}$ This weak negative correlation fails to reach conventional levels of statistical significant. The t-value equals -0.14 and the 95 percent confidence interval includes zero $(-0.63, .55)$.
} 
We also looked for a relationship between time elapsing between referral of a General Scheme and completion of PLS by a committee and number of recommendations it makes and found a weakly-positive relationship (0.12) i.e. there is a weak positive relationship between the number of recommendations a Committee makes the greater time it has to conduct PLS.

Given the rate of recommendations and the overall rate of success - some individual cases of non-change as a result of PLS notwithstanding - it appears that PLS in the Irish case does impact the content of Government legislation. It should be emphasised that the use of observational data can never provide evidence that PLS has an exclusive causal effect on the content of a Government Bill. It could be, for example, that the Department would change the content of the Bill in comparison to the content of the General Scheme even without PLS. It could also be that the legislative process would have resulted in the same impact on the legislation through the Committee's role in the legislative process. After all, even absent PLS, an Oireachtas Committee still has the opportunity to engage in an assessment of proposed legislation within its policy jurisdiction.

To test whether PLS merely replaces a Committee's impact at the formal legislative process (i.e. would have happened anyway absent PLS), we compare the Committee stages of the formal legislative process for Bills which were, and were not, subject to PLS. We use matching analysis, which is a statistical technique used to evaluate the effect of a treatment by comparing randomly chosen units from the treated and non-treated groups in an observational study. In order to randomly match a PLS and non-PLS case, we assigned numbers to each Government Bill published during the $31^{\text {st }}$ Dáil, grouping Bills by Joint Committee portfolio. We then employed a random number algorithm to select two cases - one PLS case and one nonPLS case per Joint Committee portfolio.

The results of our matching exercise, which are presented in Table 1, allow the conclusion that Bills subjected to PLS has no monotonous effect on the rate of amendments during the Committee stage of the legislative process. As we see, for example, in the comparison between the Industrial Relations Bill of 2015 with the Competition and Consumer Protection Bill in 2014, some Bills which were subjected to PLS receive fewer amendments than Bills not subject to 
PLS. In other cases, Bills which were subject to PLS receive more amendments at Committee stage, as shown in the comparison between the Assisted Decision-Making (Capacity) Bill 2013 and the Legal Services Regulation Bill 2011 at Committee stage. The importance of this exercise is that it allows us to discount the argument that PLS simply pre-empts a Committee's later role; both PLS and non-PLS Bills continue to be amended at the formal Committee stage. In other words, PLS in the $31^{\text {st }}$ Dáil has had a distinct impact on legislative outcomes; an impact separate from that of the formal legislative process.

<table 1 about here>

\section{Case study: The Gender Recognition Bill 2014}

The purpose of the case study is to probe further how PLS works in practice and uncover the mechanisms, if any, by which PLS impacts the content of legislation. The Gender Recognition Bill was selected as it had gone through the formal legislative process and was enacted, thus enabling a full analysis of the full impact of PLS, and as the quantitative analysis found that PLS had influence on the contents of the Gender Recognition Bill 2014 (a 'on the regression-line' case selection mechanism).

We trace the PLS process (and the formal legislative process), relying on official records and information from interviews with key stakeholders. These include (1) Members who served on the relevant Committees, (2) parliamentary officials who dealt with PLS, including Committee Clerks and Library \& Research staff, (3) relevant officials within Government Departments, and (4) external stakeholders who participated in PLS through the Committee's PLS submissions and hearings.

The Gender Recognition Bill was brought forward by the Government in response to a ruling of the High Court stating that Ireland was in contravention of its obligations under Article 8 of the European Convention on Human Rights by not having a process to legally recognise the acquired gender of transgender persons. Irish legislation was incompatible with the Convention regarding the registration and issue of birth certificates for people who changed their gender. The State appealed this ruling to the Supreme Court, but later withdrew the appeal. In May 2010, the Government (2007-2011) established an inter-Departmental gender 
recognition advisory group which reported to the new government (2011-2016) in August 2011. It suggested Ireland adopt a medical-based model of gender-recognition, as earlier UK legislation had done.

On $17^{\text {th }}$ July 2013, the then Minister for Social Protection, Joan Burton TD, published a General Scheme which provided for a mechanism to recognize change of gender for those over 18 who were unmarried and allowed for the acquisition of a new birth certificate that reflects this change. Minister Burton referred the General Scheme to the Joint Committee on Education and Social Protection which agreed to engage in PLS and subsequently issued a report on the General Scheme in January 2014. In June 2014, Minister Burton published a revised General Scheme for the Gender Recognition Bill 2014 and in December 2014, the Gender Recognition Bill 2014 was published and presented in Seanad Éireann. The Bill was signed into law on $22^{\text {th }}$ July 2015.

The Joint Committee shadowed two Government Departments: 'Education and Skills' and 'Social Protection, 'both large Departments, in terms of Government expenditure, services provided and political saliency, This resulted in a heavy workload for the Committee ${ }^{14}$ which comprised 21 members - fifteen Dáil deputies and six Senators. The Fine Gael-Labour coalition Government held thirteen seats on the Committee, including the Committee Chairperson, Joanna Tuffy, TD (Labour). ${ }^{15}$

On 29th August 2013, the Joint Committee invited interested individuals and groups to send written submissions on the General Scheme. Three individuals and eight groups responded to the call. Public Hearings on PLS were held on $23^{\text {th }}$ October 2013 (lasting approximately 2.5 hours), and $24^{\text {th }}$ October (lasting approximately 1.5 hours).

It was noted in interviews that it can be challenging to find time in the parliamentary schedule for Committee business. The PLS process adds greatly to the work of some Committees, particularly where the Committee is associated with a Department engaged with multiple

\footnotetext{
${ }^{14}$ Interview B.

${ }^{15}$ We use the gender-neutral term "chairperson" in contrast to the Oireachtas practice of using the word "chairman.".
} 
legislative proposals. Dáil deputies noted in several interviews that it could be difficult to balance the policy-making and oversight demands with other work in the chamber and their duties and responsibilities to constituents. ${ }^{16}$

Civil society groups engaged in the gender recognition issue were undoubtedly well represented at the PLS hearings. ${ }^{17}$ The Committee also had available expert opinion. In managing the PLS process, Committee members and parliamentary officials indicated they are mindful to seek a balanced perspective on the issues before the Committee. ${ }^{18}$ Identifying relevant actors can be challenging, including alerting potentially interested parties to the PLS process. In some cases, the Oireachtas Library \& Research Service is called upon by Committee Clerks to identify relevant exerts and interested groups. In other cases - as in this case - an open call is made to solicit submissions. Who gets to speak at PLS Committee hearings is important, in part because attendees can be very influential in shaping the content of the Committee's PLS report. Topics raised by those in attendance for the PLS hearings included:

- The sectors' general preference for a system of "self-declaration" of gender rather than the proposed bill's requirement of a physician's statement to confirm a transition. The General Scheme's system was considered by many speakers to be stigmatising and degrading;

- The age criteria for gender recognition and the possibility to change this from 18 (as proposed in the General Scheme) to 16 or perhaps even lower;

- That, unfairly, the provisions of the Bill do not apply to married people. Under head 5(d) of the General Scheme of the Bill, couples would have to divorce as a condition of recognising the transgender partner in their preferred gender;

- That schools should be issued with guidelines on gender identity issues;

- That the General Scheme's proposal to permit transgender and intersex people to be excluded from competitive sport with a view to securing fair competition and the safety of competitors be removed from the Bill; and

- To include discrimination on the grounds of transgender or intersex gender identity in equality legislation.

\footnotetext{
${ }^{16}$ Interview A, Interview B, Interview E, Interview F, and Interview L.

${ }^{17}$ Interview D.

${ }^{18}$ Interview B, Interview F, and Interview L.
} 
The Joint Committee on Education and Social Protection issued a 48-page report on the General Scheme of a Gender Recognition Bill in January 2014. As the Chair noted:

The General Scheme does not meet all of the wishes of the Groups and individuals advocating change in this area. On the other hand, some of the issues raised by the General Scheme were of particular concern to certain Members of the committee, and there was a divergence of views, especially in relation to making provision for transgender persons under the age of 18 years, and for persons who are married or in a civil partnership. ${ }^{19}$

In addition to summarising the content of the submissions and public hearings, the committee made seven recommendations in relation to the General Scheme of Gender Recognition Bill 2013:

Terminology: Consideration should be given to whether the term "preferred gender" should replace the term "acquired gender" in the Bill;

Age Criterion: The committee recommended that the age at which a person is entitled to apply for a Gender Recognition Certificate should be reduced from 18 years to 16 years. In addition, measures should also be taken to address the day-to-day concerns of transgender people under the age of 16 years;

Single Criterion: The committee believes that if a person is in an existing marriage or a civil partnership, this should not prevent him or her from qualifying for a Gender Recognition Certificate, and urges the Minister to revisit this issue;

Evidence of Transition: The committee recommended that the current wording in the Bill with respect to evidence of transition should be reconsidered. The wording should address the concerns regarding people being stigmatised because of requirements like this;

Guidelines for Schools: The committee recommended that guidelines on supporting the inclusion of transgender young people in schools should be developed;

Participation in Sport: The provisions in the General Scheme regarding sport organisations should be reconsidered. Irish sporting regulatory bodies receiving public funding should develop comprehensive policies in relation to the participation of transgender people; and

\footnotetext{
${ }^{19}$ Joint Committee on Education and Social Protection (2014: 4).
} 
Equality Acts: Consideration should be given to amending equality legislation to add "gender identity" to the existing nine grounds under which discrimination is illegal.

In a parliamentary debate on the PLS Report, the then Minister for Social Protection, Joan Burton TD, noted that: "The contents of the report of $14^{\text {th }}$ January and the contributions made at the hearings the committee held on $23^{\text {th }}$ and $24^{\text {th }}$ October 2013 have made an important and valuable contribution to the overall understanding of the complex issues that are being addressed in this legislation." 20

Minister Burton declined to elaborate further on the effect of the PLS as the General Scheme was being returned to the Cabinet for approval. In fact, the Committee's PLS report had such a significant impact on the General Scheme that it could no longer be employed to prepare the full draft of the Bill. ${ }^{21}$ Instead, a revised General Scheme was drafted and sent to Cabinet for approval. Minister Burton noted: "the Government agreed when discussing the general scheme of the Bill last year that if significant changes to the legislation were recommended by the committee, I would bring the matter back to Cabinet for the committee's recommendations to be considered." 22

In June 2014, the Cabinet approved the revised General Scheme of Gender Recognition Bill 2014, and the Bill was subsequently published in December. In exploring the Bill, it is possible to observe the changes to the Bill as a result of PLS. ${ }^{23}$ The same is observed in the communications between the Department and the Houses of the Oireachtas Service.

With regard to the Committee's first recommendation, the then Minister accepted the change in terminology. The term "preferred gender" replaced the term "acquired gender" in the Bill. It could be argued that this was both a symbolic change, but also a substantive change recognising the right of individuals to prefer a gender. With regard to the Committee's second recommendation, the revised draft legislation now provided that those aged 16 and 17 could

\footnotetext{
${ }^{20}$ Dáil Debates, Friday, 9 May 2014.

${ }^{21}$ Interview C.

22 Dáil Debates, Friday, 9 May 2014.

${ }^{23}$ Oireachtas Library \& Research Service 2015.
} 
have their gender change recognised, although the process required the involvement of a judge. Providing this pathway for those aged 16 and 17 was a clear response to the PLS process. Appearing before the Committee's PLS public hearing on 23th October 2013 the Department representative, Ms Simonetta Ryan, noted that, "[t]he Government made a very clear decision that the age would be 18 years. The legislation is being drawn up on that basis." The Government's position changed as a result of the PLS process. ${ }^{24}$

The Committee's third recommendation to remove the unmarried criteria was not accepted by Minister Burton. The Department faced a legal problem in that the Irish Constitution at that time specifically forbid recognition of a marriage between two people of the same gender. In its reply to the Oireachtas Library \& Research Service, the Department noted that, "[i]t was decided to legislate now for the large majority of the people affected who are single, and await the outcome of the referendum on same-sex marriage due to be held in May [2015]". ${ }^{25}$

The Committee's fourth recommendation regarding evidence of transition was arguably relatively vague and made a direct change difficult. For example, the recommendation did not clearly specify an alternative mechanism to recognise gender change. The Department did move some way to addressing the Committee's recommendations, although at this stage it did not adopt the "self-declaration" model suggested by a number of groups during the PLS hearing. ${ }^{26}$ With regard to the Committee's fifth recommendation (school guidance), no changes to the Bill were made. The Department felt school guidance was an issue for the Department of Education and Skills, but the then Minister for Social Protection did write to the then Minister for Education and Skills, Ruairi Quinn TD in that regard. The Department subsequently worked with stakeholders to produce a guide for post-primary schools - Being LGBT in School. ${ }^{27}$

In a clear case of direct causal impact, the Committee's sixth proposal (participation in sport) resulted in the removal of the section which permitted transgender and intersex people to be

\footnotetext{
${ }^{24}$ Interview A.

${ }^{25}$ Oireachtas Library \& Research Service 2015.

${ }^{26}$ Interview C.

${ }^{27}$ Available at: https://www.education.ie/en/Publications/Education-Reports/Being-LGBT-inSchool.pdf
} 
excluded from competitive sports. That clause was originally based on a similar clause in UK legislation, but at the PLS the civil society sector suggested this would severely hinder transgender people's participation in sports. ${ }^{28}$

The Committee's final recommendation - specifying gender identity as a ground for discrimination - was considered, but the Department made no change to the proposed legislation in this regard. As the Department explained: "[t]his issue was not included as legal advice sought indicates that it is not necessary to add explicit provisions in respect of equality for transgender persons and intersex persons as discrimination on the basis of transgender status was already prohibited under the gender ground."29

There is clear evidence that significant changes were made to the substance of the proposed legislation as a direct result of the PLS process. However, the Ministers did not simply accept all seven recommendations from the Committee. From the Department's perspective, PLS resulted in "a lot of learning" and this learning formed the basis for the changes to the General Scheme. These changes necessitated bringing the General Scheme back before Cabinet, with significant consequences for the content of the subsequent Bill. ${ }^{30}$

In the case of the Gender Recognition Bill, the influence of PLS extended beyond changes to the General Scheme and the published Bill. The process also influenced subsequent parliamentary debate and ultimately led to a crucial amendment during the formal legislative process. After the initial parliamentary debates, and under significant pressure, the Minister agreed to consult further on the need to involve a medical practitioner in the gender recognition process. ${ }^{31}$ Subsequent to this, it was announced that trans-people over the age of 18 would be able to self-declare their gender identity without requirement of certification from a medical practitioner. The Bill was revised in the Select Sub-Committee meeting on 17th June and all medical criteria for individuals over 18 was removed. In other words, "self-declaration" was to be the basis of the decision. The removal of the term "medical evaluation" spoke

\footnotetext{
28 Interview D.

${ }^{29}$ Oireachtas Library \& Research Service (2015).

${ }^{30}$ Interview C and Interview D.

${ }^{31}$ Interview D.
} 
directly to the fourth recommendation in the Committee's PLS Report. The proposed requirement of a primary treating physician confirming the person has transitioned or is transitioning to their acquired gender represents another significant change to the Bill. This was actioned during the legislative process, but was very much a result, in our assessment, of the Committee's PLS Report and parliament's positive response to the content of that report.

The Chairperson of the Committee which undertook PLS of the Gender Recognition Bill stated: it was very good for us to see the result of the work we had put into it being taken on board by the Minister and the Minister of State and their officials. ${ }^{32}$

Interviews with parliamentarians and parliamentary staff suggest that the composition of the Committee, in terms of which individuals that serves, is very important for the success of PLS - and Committee activity in general. Where one or more members of the Committee have a pre-existing interest in the substance of the proposed legislation, the PLS process tends to be more active. This, it was suggested, was the case for the Gender Recognition Bill. ${ }^{33}$ One member, Deputy Aengus Ó Snodaigh, had previously introduced a Private Members' Bills on the topic of gender recognition.

Interestingly, the committee's recommendations closely, though note perfectly, reflect core concerns of civil society groups included in the PLS process. As such, the Committee appears to have been acting as a conduit for the civil society groups. It should be noted that this might simply reflect the prior preferences of members of the Committee. However, it underlines the importance of a transparent and objective process for identifying stakeholders and experts, already-identified by the committee secretariat and noted above.

\section{Conclusion}

How successful are attempts to strengthen the capacity of national legislatures to better perform their law-making function? Our analysis of the introduction of PLS into the Irish legislative process indicates that attempts to strengthen the capacity of national legislatures

\footnotetext{
${ }^{32}$ Gender Recognition Bill 2014: Committee Stage. Wednesday, $17^{\text {th }}$ June 2015

${ }^{33}$ Interview A and Interview B.
} 
can be effective, even in legislatures that tend to be dominated by the executive. Given the overall rate of acceptance of PLS proposals (41.7\%), and notwithstanding some individual cases where no recommendations were accepted or made, it appears that PLS in the Irish Parliament has had a direct impact on the content of Government legislation. Using matching analysis, where Committee amendments (at formal Committee stage) were compared for Bills subject to PLS with Bills not subject to PLS, we can discount the argument that PLS simply pre-empts a Committee's later role. Both PLS and non-PLS Bills continue to be amended at the formal Committee stage, and it is not the case that PLS merely replaces a Committee's role in the formal legislative process.

While not every Bill is altered fundamentally by PLS, some are. For example, the impact of PLS on the Gender Recognition Bill was to change core parts of the Bill, affecting the ability of those under 18 to have their gender recognised, and changing - arguably quite dramatically - the mechanism by which those over 18 have their gender choice recognised by the State. A revised General Scheme was brought to Cabinet as a direct consequence of PLS. Further, one of the most interesting features of PLS is how it may continue to exert influence once a Bill is introduced into Parliament. Issues raised in submissions and hearings for PLS and/or the recommendations of the Committee can frame subsequent legislative debate on the issue, as demonstrated in the Gender Recognition Bill. We can thus speak of a potential effect of PLS both during the drafting and in the formal legislative process after a Bill has been presented in the Oireachtas. Members of the Oireachtas do refer to the PLS process during parliamentary debates on Bills.

This paper has demonstrated that PLS can have a significant impact on legislative outcomes and did so in the 31 $1^{\text {st }}$ Dáil (2011-2016). Yet PLS does not always lead to significant changes in legislation. While this may be related to the piece of legislation in question, we consider that other factors may be at play. We found correlations (albeit weak correlations) between the time available to a committee to undertake PLS and its capacity to influence the outcome, which may indicate that PLS will be more effective when fully built-into the legislative drafting process i.e. government waits for committee report before formally drafting the bill. 
Further, while one might expect PLS to have a greater impact on legislative outcomes where a minority government is in place (as committees are not [as] dominated by government and government may need to accept the recommendations of opposition), the experience of the $31^{\text {st }}$ Dáil suggests that it can be successful where a majority-coalition government is in place (especially where that government supports the process). To ensure the commitment of the $32^{\text {nd }}$ Dáil to the PLS process, the Dáil recently approved amendments to Standing Orders which stipulate that where a government minister proposes that due to exceptional circumstances PLS of a General Scheme should be waived, he or she must win the approval of the Business Committee. ${ }^{34}$ Success equally depends on Ministers referring General Schemes to the relevant Committee immediately after it has been approved at cabinet and in a transparent manner.

\footnotetext{
${ }^{34}$ Dáil Standing Orders 2016 (Consolidated Version January 2019). Standing Order 146A
} 


\section{Bibliography}

André, Audrey, Sam Depauw, and Shane Martin (2016) "Trust Is Good, Control Is Better: Multiparty Government and Legislative Organization." Political Research Quarterly 69(1): 108120.

Arkins, Audrey (1988) "The Committees of the 24th Oireachtas." Irish Political Studies 3: 9197.

Gallagher, Michael (2010) "Parliamentary Parties and the Party Whips," in Muiris MacCarthaigh and Maurice Manning (eds.) The Houses of the Oireachtas: Parliament in Ireland. Dublin: Institute of Public Administration, pp. 129-152.

Gallagher, Michael, and Michael Marsh, eds. (2011) How Ireland Voted 2011: The full story of Ireland's earthquake election. Basingstoke: Palgrave Macmillan.

Goodwin, Mark, and Stephen Bates (2016) "The 'powerless parliament'? Agenda-setting and the role of the UK parliament in the Human Fertilisation and Embryology Act 2008." British Politics 11(2): 232-255.

Kalitowski, Susanna (2008) "Rubber stamp or cockpit? The impact of parliament on Government legislation." Parliamentary Affairs 61(4): 694-708.

Koß, Michael (2018) Parliaments in Time: The Evolution of Legislative Democracy in Western Europe, 1866-2015. Oxford: Oxford University Press.

Korris, Matt (2011) "Standing up for Scrutiny: How and Why Parliament Should Make Better Law." Parliamentary Affairs 64(3): 564-574.

Leston-Bandeira, Cristina, and Louise Thompson (2017) "Integrating the view of the public into the formal legislative process: public reading stage in the UK House of Commons." The Journal of Legislative Studies. Online first: 10.1080/13572334.2017.1394736

Lynch, Catherine. 2017. "The effect of parliamentary reforms (2011-16) on the Oireachtas committee system." Administration 65(2): 59-87.

Lynch, Catherine, Eoin O'Malley, Theresa Reidy, David M. Farrell, and Jane Suiter (2017) "Dáil reforms since 2011: Pathway to power for the 'puny' parliament?." Administration 65(2): 3757.

Martin, Shane (2010) "The Committee System," in Muiris MacCarthaigh and Maurice Manning (eds). The Houses of the Oireachtas: Parliament in Ireland. Dublin: Institute of Public Administration, pp. 285-302.

Martin, Shane Thomas Saalfeld, and Kaare W. Strom, eds. (2014) The Oxford Handbook of Legislative Studies. Oxford: Oxford University Press.

Martin, Shane, and Richard Whitaker (2019) "Beyond committees: parliamentary oversight of 
coalition government in Britain." West European Politics. doi.org/10.1080/01402382.2019.1593595

MacCarthaigh, Muiris (2011) "Parliamentary Scrutiny of Departments and Agencies," in Muiris MacCarthaigh and Maurice Manning, eds., The Houses of the Oireachtas: Parliament in Ireland. Dublin: Institute of Public Administration, pp. 358-376.

MacCarthaigh, Muiris (2005) Accountability in Irish Parliamentary Politics. Dublin: Institute of Public Administration.

Modernisation Committee, The Legislative Process. $7^{\text {th }}$ September 2006, HC 1097 2005-06.

Murphy, Mary C. (2006) "Reform of Dáil Éireann: The dynamics of parliamentary change." Parliamentary Affairs 59: 437-453.

Norton, Philip (2017) “Speaking for Parliament." Parliamentary Affairs 70(2): 191-206.

Norton, Philip (2013) Parliament in British Politics. Basingstoke: Palgrave Macmillan.

O'Malley, Eoin, and Muiris MacCarthaigh (2011) Governing Ireland: From Cabinet Government to Delegated Governance. Dublin: Institute of Public Administration.

O'Malley, Eoin and Shane Martin (2018) "The Government and the Taoiseach" in John Coakley and Michael Gallagher, eds. Politics in the Republic of Ireland, 6th edition. Abingdon: Routledge, pp. 243-269.

Oireachtas Joint Committee on Education and Social Protection (2014) Report on the General Scheme of a Gender Recognition Bill 2013.

Oireachtas Library \& Research Service (2016) Pre-legislative scrutiny (PLS) by parliament. Spotlight, No. 8 of 2014 (Appendix and figures Updated April 2016).

Oireachtas Library \& Research Service (2015) Bills Digest: Gender Recognition Bill 2014. No. 116 of 2014. 20th January 2015.

Power, Greg (2000) Parliamentary Scrutiny of Draft Legislation 1997-1999. London: UCL Constitution Unit.

Programme for Government 2011-2016. Dublin: Department of the Taoiseach.

Russell, Meg, and Daniel Gover (2017) Legislation at Westminster: Parliamentary Actors and Influence in the Making of British Law. Oxford: Oxford University Press.

Sieberer, Ulrich, Peter Meißner, Julia F. Keh, and Wolfgang C. Müller (2016) "Mapping and explaining parliamentary rule changes in Europe: A research program." Legislative Studies Quarterly 41(1): 61-88.

Smookler, Jennifer (2006) "Making a difference? The effectiveness of pre-legislative scrutiny." 
Parliamentary Affairs 59(3): 522-535.

Strøm, Kaare (1998) "Parliamentary Committees in European Democracies." Journal of Legislative Studies 4(1): 21-59.

Widdecombe, Ann (2005) "The Role of an MP: An Opposition view," in Nicholas Baldwin (ed.) Parliament in the 21st Century. London: Politico. 
Table 1: Accepted Committee-Stage Amendments, Select Bills, $31^{\text {st }}$ Dáil

\begin{tabular}{|c|c|c|c|}
\hline PLS Bill & Non PLS Bill & $\begin{array}{c}\text { PLS Bill } \\
\text { Committee } \\
\text { Amendments }\end{array}$ & $\begin{array}{l}\text { Non-PLS Bill } \\
\text { Committee } \\
\text { Amendments }\end{array}$ \\
\hline & Animal Health and Welfare Bill & & \\
\hline Horse Racing Ireland Bill 2015 & 2012 & 21 & 29 \\
\hline Education and Training Boards & Further Education and Training & & \\
\hline Bill 201 & Bill 2013 & 37 & 23 \\
\hline $\begin{array}{l}\text { National Cultural Institutions } \\
\text { (National Concert Hall) Bill }\end{array}$ & $\begin{array}{c}\text { Local Government } \\
\text { (Miscellaneous Provisions) Bill }\end{array}$ & & \\
\hline 2015 & 2012 & 3 & 11 \\
\hline Freedom of Information Bill & Microenterprise Loan Fund Bill & & \\
\hline 2013 & 2012 & 16 & 0 \\
\hline Public Health (Standardised & Public Health (Tobacco) & & \\
\hline Packaging of Tobacco) Bill 2014 & (Amendment) 2011 Bill & 0 & 0 \\
\hline Industrial Relations & Competition and Consumer & & \\
\hline (Amendment) Bill 2015 & Protection Bill 2014 & 17 & 43 \\
\hline Assisted Decision-Making & Legal Services Regulation Bill & & \\
\hline (Capacity) Bill 2013 & 2011 & 388 & 80 \\
\hline State Airports (Shannon Group) & National Tourism Development & & \\
\hline Bill 2014 & Authority (Amendment) Bill 2011 & 4 & 0 \\
\hline
\end{tabular}


Figure 1: Number of PLS by Joint Committee, $31^{\text {st }}$ Dáil.

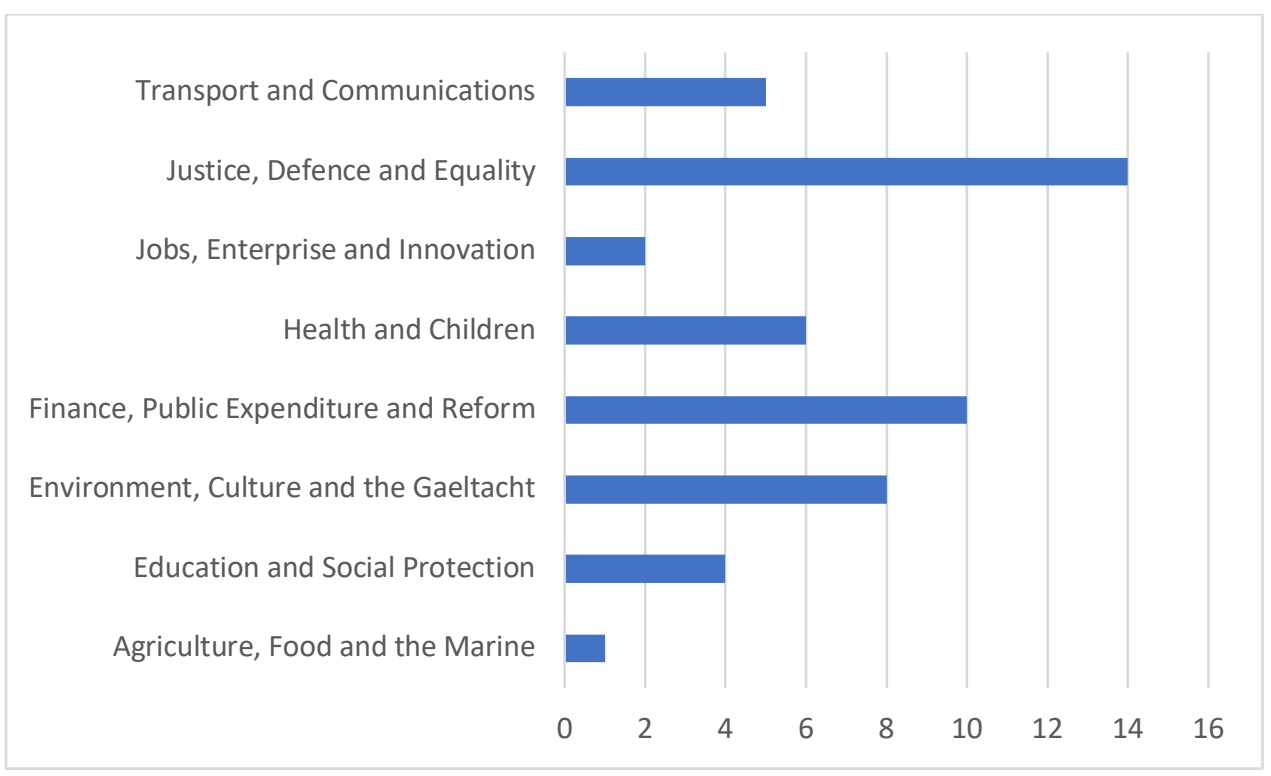


Figure 2: Rate of PLS Recommendations by Committee, $31^{\text {st }}$ Dáil.

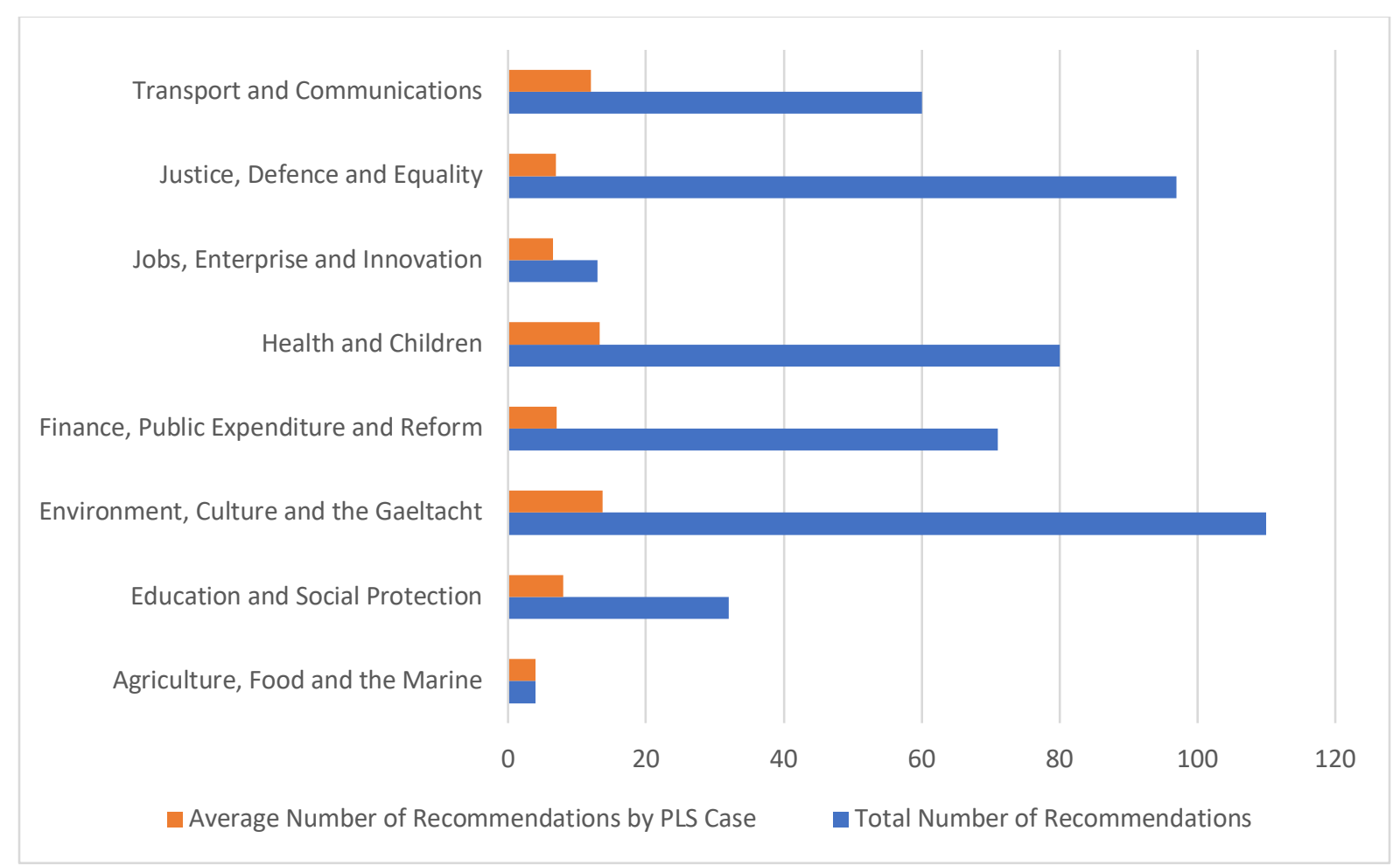


Figure 3: PLS Recommendation Acceptance, by Oireachtas Committee, $31^{\text {st }}$ Dáil.

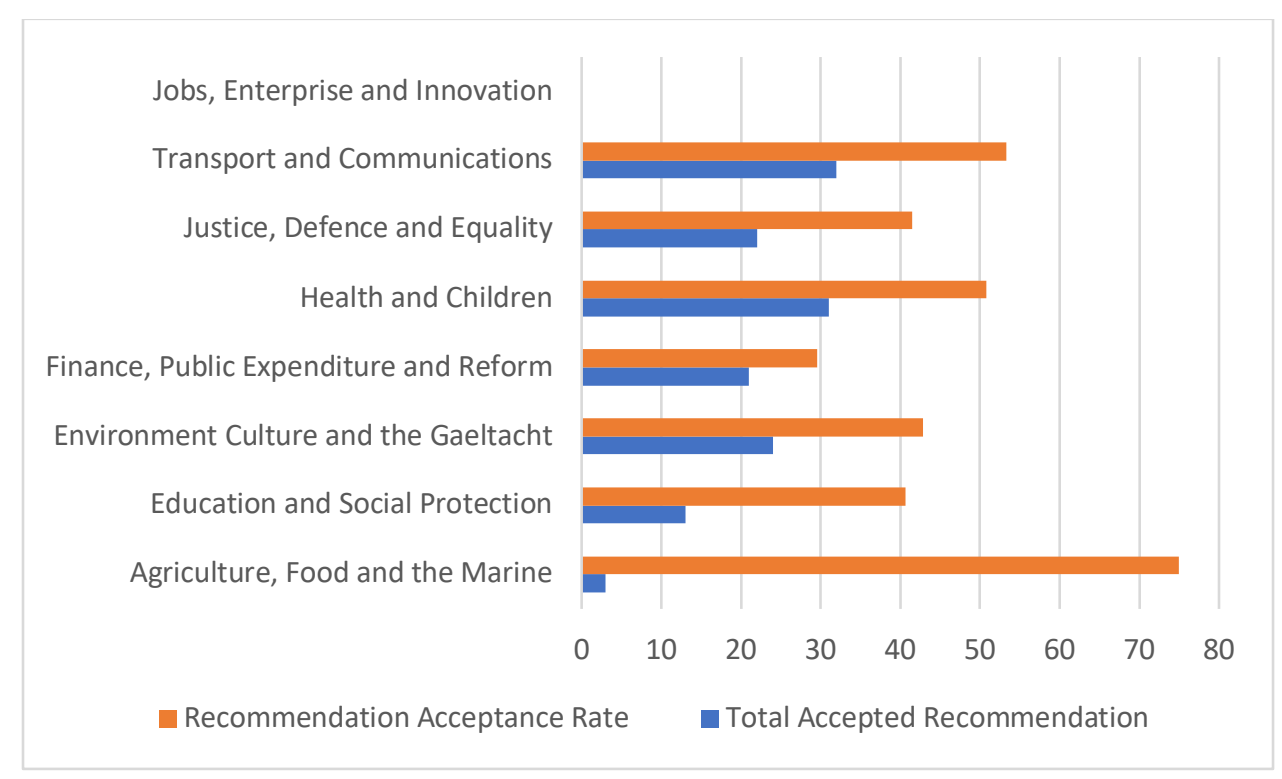

Note: Includes only cases where recommendations were made and a bill was published. 